\title{
Article \\ The State of Soil Organic Carbon in Vineyards as Affected by Soil Types and Fertilization Strategies (Tri Morave Region, Serbia)
}

\author{
Snežana Jakšić ${ }^{1, *(D)}$, Jordana Ninkov ${ }^{1} \mathbb{D}$, Stanko Milić $^{1} \mathbb{D}$, Jovica Vasin ${ }^{1}$, Dušana Banjac ${ }^{1}$, Darko Jakšić ${ }^{2}$ and $^{1}$ \\ Milorad Živanov ${ }^{1}$
}

1 Laboratory for Soil and Agroecology, Institute of Filed and Vegetable Crops, National Institute of the Republic of Serbia, 21000 Novi Sad, Serbia; jordana.ninkov@ifvens.ns.ac.rs (J.N.); stanko.milic@ifvcns.ns.ac.rs (S.M.); jovica.vasin@ifvens.ns.ac.rs (J.V.); dusana.banjac@ifvens.ns.ac.rs (D.B.); milorad.zivanov@ifvens.ns.ac.rs (M.Ž.)

2 Center for Viticulture and Oenology, 11111 Belgrade, Serbia; d.jaksic@cevvin.rs

* Correspondence: snezana.p.jaksic@gmail.com; Tel.: +381-21-4898-463

check for updates

Citation: Jakšić, S.; Ninkov, J.; Milić, S.; Vasin, J.; Banjac, D.; Jakšić, D.; Živanov, M. The State of Soil Organic Carbon in Vineyards as Affected by Soil Types and Fertilization Strategies (Tri Morave Region, Serbia). Agronomy 2021, 11, 9. https://dx.doi.org/10.3390/ agronomy11010009

Received: 29 November 2020 Accepted: 19 December 2020 Published: 23 December 2020

Publisher's Note: MDPI stays neutral with regard to jurisdictional claims in published maps and institutional affiliations.

Copyright: () 2020 by the authors. Licensee MDPI, Basel, Switzerland. This article is an open access article distributed under the terms and conditions of the Creative Commons Attribution (CC BY) license (https: / / creativecommons.org / licenses/by/4.0/).

\begin{abstract}
Due to specific soil properties and management practices, soils in vineyards are sensitive to degradation. The aims of this study were to examine (i) the state of soil organic carbon (SOC) in vineyards compared to other agricultural land, (ii) the influence of different fertilization strategies and soil type on SOC content and (iii) the rate of SOC change over time and potential of deep tillage for SOC preservation in subsoil. The study was carried out at 16 representative vineyard locations of the Tri Morave region, which represents the largest vine growing region in Serbia. The analyzed area included 56 vineyard plots. Results showed that SOC stocks in the topsoil and subsoil were lower than the average for agricultural land in Serbia. The soil type was an important predictor of carbon storage in the topsoil. An adequate application of inorganic fertilizers or green manure combined with farmyard manure initially resulted in the highest SOC contents. Continuous application of inorganic fertilizer without organic amendments has led to a decrease of SOC in topsoil. High rates of SOC stock change in topsoil accompanied a rapid reduction of SOC in the earlier stage of cultivation. In all investigated subsoils, SOC increased, except for unfertilized vineyards. Deep tillage has the potential to preserve SOC in the deeper soil layer and prevent carbon loss from the topsoil. More attention should be paid to the soil conservation practices to meet environmental sustainability of viticulture.
\end{abstract}

Keywords: soil; soil organic carbon; viticulture; fertilization strategies

\section{Introduction}

Soil is an unrenewable natural resource and plays a key role in terrestrial ecosystems. Soil organic matter (SOM) is an essential component of soils as it supports soil structure, fertility and a range of physical properties that positively affect water availability to plants [1,2]. Consequently, a decrease of SOM can lead to drastic impairment of the soil physical and chemical properties, with negative impacts on soil nutrient cycling mechanisms $[3,4]$. In the light of the climate change debate, SOM is furthermore seen as an important storage pool for carbon. Soil organic carbon (SOC) sequestration is regarded as an option to mitigate climate change. Against this background, extensive research efforts have been devoted to the study of the terrestrial carbon cycle [5-9].

The strategy of SOC sequestration is built on a positive SOC budget for specific land use and management systems, whereby the input of $C$ into soils exceeds the losses of SOC through erosion, mineralization/volatilization and leaching [10]. The total SOC stock of planet Earth has been estimated to be around $1500 \mathrm{Pg}$ in the upper $100 \mathrm{~cm}$ of soil $(700 \mathrm{Pg}$ in the upper $30 \mathrm{~cm}$ ), approximately three times higher than in the vegetation and double than in the atmosphere (about 560 and $760 \mathrm{Pg}$, respectively) [11-16]. The estimation of the global SOC stock up to $2 \mathrm{~m}$ depth is $2060 \pm 215 \mathrm{Pg}$ [17]. These values represent only 
a rough estimation, with errors estimated as between 504 and $3000 \mathrm{Pg}$ [18]. Due to the high potential of soils for carbon sequestration, the " 4 per 1000 " international initiative was launched in Paris in 2015 [19] to increase the awareness of land use responsibility for climate change.

One of the main factors that control the vertical distribution of SOC is land use [14,20]. Changes in land use are the second most important source of GHG emissions to the atmosphere after fossil fuel burning [21]. According to Wiesmeier et al. [22], the main factors affecting the variation in SOC stocks in Bavaria (Germany) are land use and soil type. Other factors include farming/cropping systems, adoption of recommended management practices, tillage methods, use of organic and inorganic amendments etc. [10]. The factors responsible for the differences in SOC stocks can also differ with soil depth [23]. Hobley et al. [24] found that climatic factors have more effect at shallow depths, while site factors such as bulk density, soil type and parent rock became more important at depths below $20 \mathrm{~cm}$.

In the vine-growing areas of the Republic of Serbia, frequent tillage between the rows is a common practice to keep the soil free of weeds. Such intensive working of vineyard soils can lead to soil degradation, with loss of soil fertility, acceleration of soil erosion and SOM mineralization, and $\mathrm{CO}_{2}$ emission increase [25-27]. Due to specific soil properties in vineyards such as limited soil development, coarse texture and low capacity to protect SOM binding to soil minerals, these soils are sensitive to degradation [28-30] and lose potentially more SOM than other agricultural soils.

According to the assessment of the SOC stock in the vineyards of European countries, similar stocks were reported. The mean SOC stock in Italy in the top $30 \mathrm{~cm}$ of mineral soil of the vineyards was $41.9 \pm 15.9 \mathrm{t} \mathrm{ha}^{-1}$ [31]. The SOC stocks in vineyards of France were $39.4 \pm 26.5 \mathrm{t} \mathrm{ha}^{-1}$ [32]. In peninsular Spain, $42.5 \pm 28.9 \mathrm{t} \mathrm{C} \mathrm{ha}^{-1}$ was reported for vineyards [33].

Fertilization is one of the most important practices in crop production, and in intensive viticulture production in Serbia exclusively inorganic fertilizers are applied. Organic materials are rarely applied, only when establishing vineyards. Organic matter input from grapevine residues is limited, because Serbian winegrowers commonly do not bring grape pomace back to the soils. Some wine producers avoid using organic fertilizers for grape production, because they fear negative effects on the quality of the grapes. This practice potentially aggravates the decrease of SOC, which directly jeopardizes the long-term maintenance of soil quality. There is concern that if SOC content in vineyard soils is allowed to decrease beyond a critical threshold, the productive capacity of viticulture will be compromised by further deterioration in soil physical properties and by deterioration of soil nutrient cycling mechanisms [34]. However, to date there is no systematic monitoring of Serbian vineyard SOC contents available and long-term dynamics have also not been studied so far.

The aim of this study was to examine (i) the state of SOC in vineyards compared to other agricultural land, (ii) the rate of SOC change over time, (iii) the influence of different fertilization strategies and soil type on current SOC contents and (iv) the influence of deep tillage on SOC preservation in the deeper soil layer as a counterbalance against C losses in the topsoil.

\section{Materials and Methods}

\subsection{Study Area}

The study area is the vineyard region Tri Morave, Serbia (Figure 1), which represents the largest vine growing region in Serbia, with a surface area of $286,929 \mathrm{~km}^{2}$. This region is located between $43^{\circ} 21^{\prime} \mathrm{N}$ and $44^{\circ} 07^{\prime} \mathrm{S}$ and includes the areas around three large rivers in Central Serbia, the wide lower basin of the Zapadna Morava River, the lower basin of the Južna Morava River and the wider upper basin of the Velika Morava River [35]. 


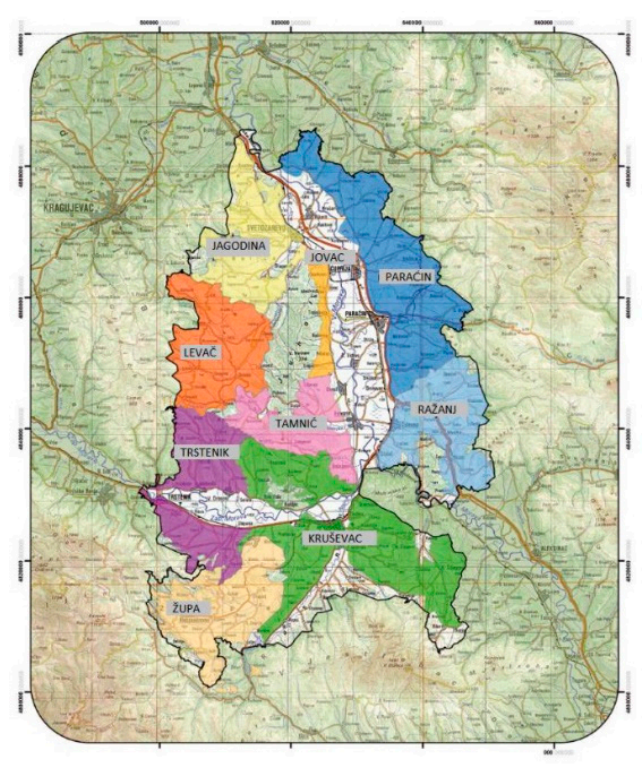

(a)

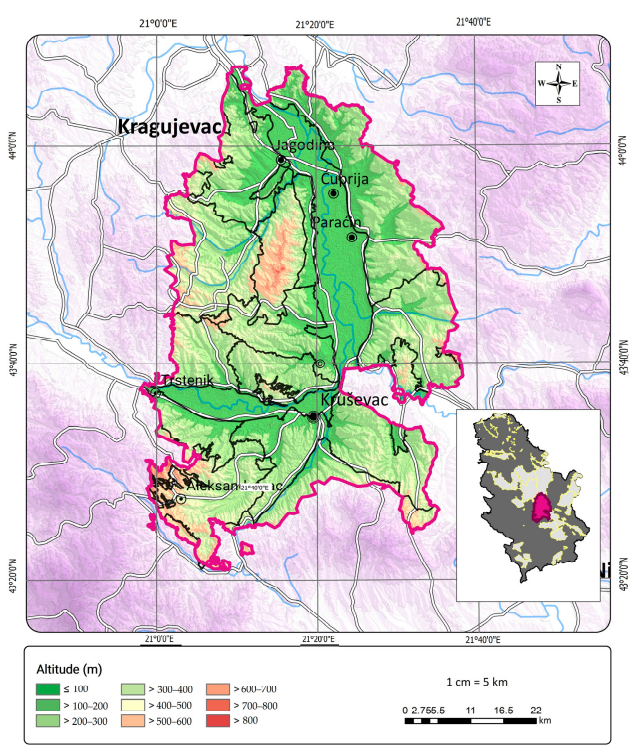

(b)

Figure 1. The vineyard region Tri Morave, Serbia: (a) vine growing districts (modified by authors) [36] and (b) topographic map.

Total areas of individual wine growing districts are much smaller than the areas of the subregions. Conversely, areas under vineyards are far smaller than the distribution of each wine growing district, as well as areas that have the potential for wine growing production. These areas have been increasing in recent years. Tri Morave vine region has $75.28 \mathrm{~km}^{2}$ of vineyards from which $13.67 \mathrm{~km}^{2}$ include table varieties and $61.61 \mathrm{~km}^{2}$ include wine varieties [35].

Although it has a wide range of grape varieties, it is mostly well-known for its black grape varieties used in production of high quality red, but also rosé wines. The most widespread black varieties are Cabernet Sauvignon and Merlot. There are nine vine growing districts in this region: Paraćin, Jagodina, Jovac, Levač, Temnić, Trstenik, Kruševac, Župa and Ražanj [36].

The Tri Morave wine region possesses favorable climatic conditions for vine growing. The average annual air temperature, for the last 50 years, is $11.4{ }^{\circ} \mathrm{C}$ and the average annual precipitation is $644 \mathrm{~mm}$. The heat summation period (April-October), also known as the Winkler index, is 1571.5, placing the Tri Morave wine region in the II zone according to Winkler [36]. Most of the vineyards in the region are located on slopes (Figure 1b). The majority of them (49\%) slope between 5 to 10 degrees, about 10\% slope between 10 to 15 degrees and about $36 \%$ are located on flatter terrain [37].

There are three basic geomorphological units: alluvial plains of the Južna, Zapadna and Velika Morava rivers, dissected fluvial terraces in the zone of low hills and the mountain zone (Figure 2B). Since the parent substrate represents an essential determinant of geochemical, mineralogical and granulometric properties of soils, the Tri Morave wine region has a moderate pedological diversity dominated by different varieties of only two types of soil: cambisols and vertisols (Figure 2A) [37]. 


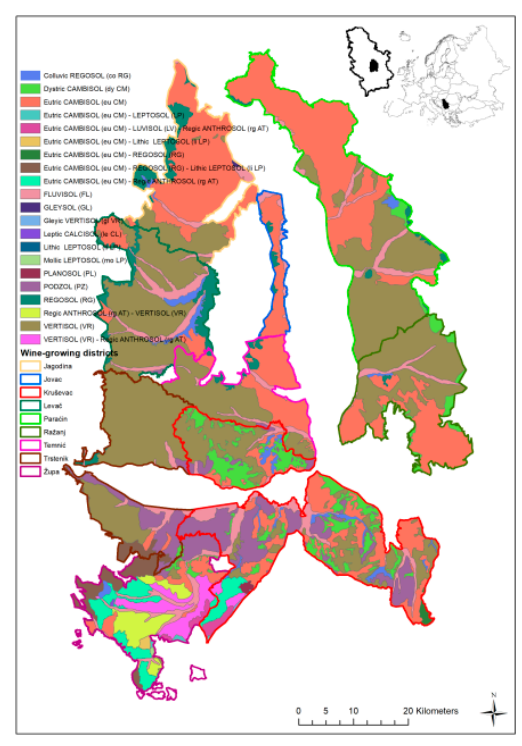

(A)

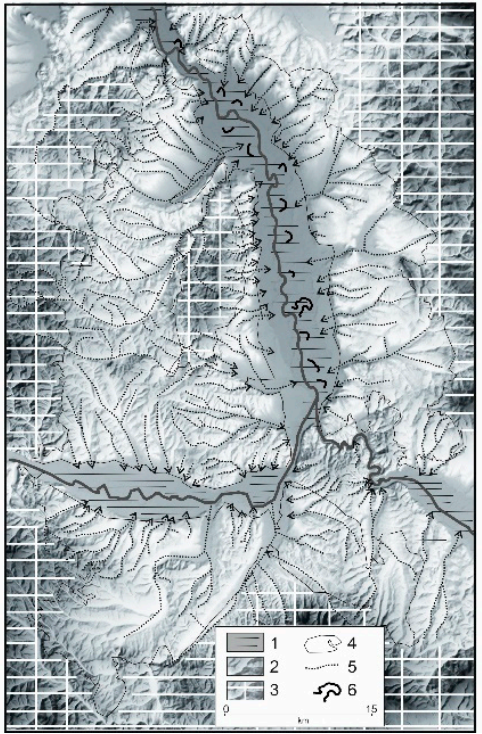

(B)

Figure 2. (A) Pedological map of the Tri Morave vineyard region and borders of vine growing districts, according the World Reference Base (WRB) soil classification, based on digitalized primary pedological map of the Republic of Serbia 1: 50,000. (B) Geomorphological map (1-alluvial plains, 2-dissected fluvial terraces in the zone of low hills, 3-mountain relief zone, 4-borders of the Tri Morava vineyard region, 5-a smaller river valley, 6-paleomeander).

\subsection{Soil Sampling}

The study was carried out in 16 representative vineyard locations (Figure 3 and Figure S1, and Table 1). The total analyzed area included 56 production vineyard plots. These plots exhibit a uniform microrelief and slope of the terrain, as well as having the same cultivation practices. The size of the plot (subplot) varied from 6000 to $40,000 \mathrm{~m}^{2}$.

Table 1. Locations, vine growing districts and soil types of the vineyards.

\begin{tabular}{llll}
\hline No & Locality & Vine Growing District & Soil Type (FAO-WRB) \\
\hline 1 & Levač & Levač & Haplic Vertisol (Clayic) \\
2 & Dobričevo & Paraćin & Eutric Cambisol \\
3 & Glavica & Levač & Haplic Vertisol (Clayic) \\
4 & Oparić & Paraćin & Stagnic, Eutric Cambisol \\
5 & Lozovik & Jagodina & Eutric Cambisol (Clayic) \\
6 & Lučina & Kruševac & Eutric Cambisol (Clayic) \\
7 & Ravnjak & Kruševac & Eutric Cambisol (Clayic) \\
8 & Bučje & Trstenik & Skeletic Leptosol (Clayic) \\
9 & Trstenik & Trstenik & Eutric Cambisol (Clayic) \\
10 & Bačina & Temnić & Eutric Cambisol (Clayic) \\
11 & Lipovac & Ražanj & Eutric Cambisol (Clayic) \\
12 & Gornje Zleginje & Župa & Haplic Vertisol \\
13 & Donje Zleginje & Župa & Haplic Vertisol \\
14 & Tržac & Župa & Eutric Cambisol (Clayic) \\
15 & Aleksandrovac & Župa & Haplic Vertisol \\
16 & Aleksandrovac & Župa & Gleyic, Skeletic Fluvisol \\
& & & (Clayic) \\
\hline
\end{tabular}




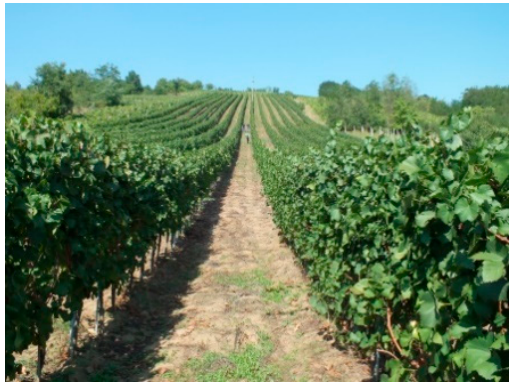

(a)

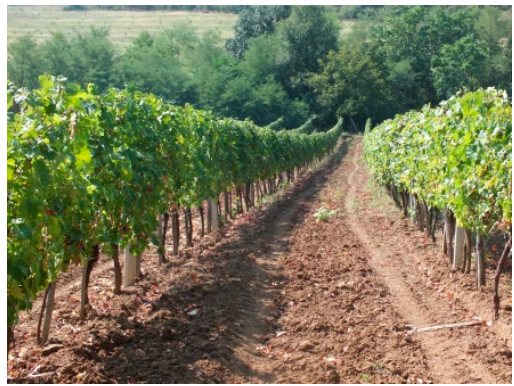

(b)

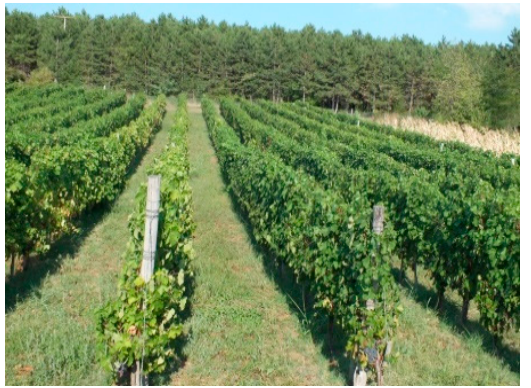

(c)

Figure 3. Some localities of observed vineyards: (a) Trstenik, (b) Bačina, (c) Glavica.

The soil was sampled from two depths, 0-30 and 30-60 cm, composing a mixed sample from 20 individual samples. The total number of the mixed soil samples was 112 .

In order to determine the indigenous soil type of the vineyard, which was not altered by powerful ameliorative measures (deep tillage) during the vineyard establishment and turned into an Anthrosol (Eutric, Clayic, Regic), AT-eu.ce.rg, soil profiles were opened in a nondisturbed site of vineyards (Figure 4).

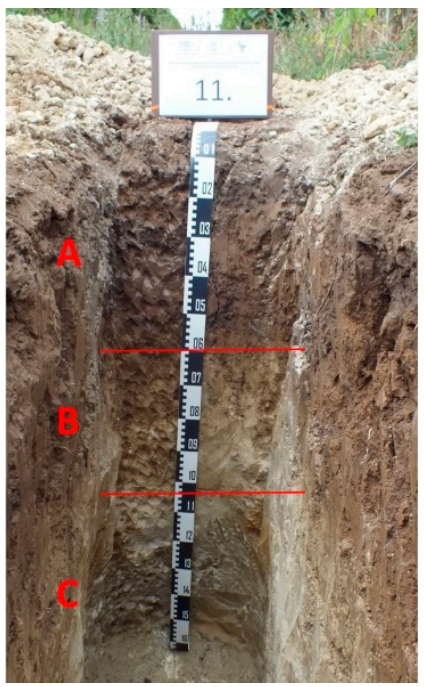

(a)

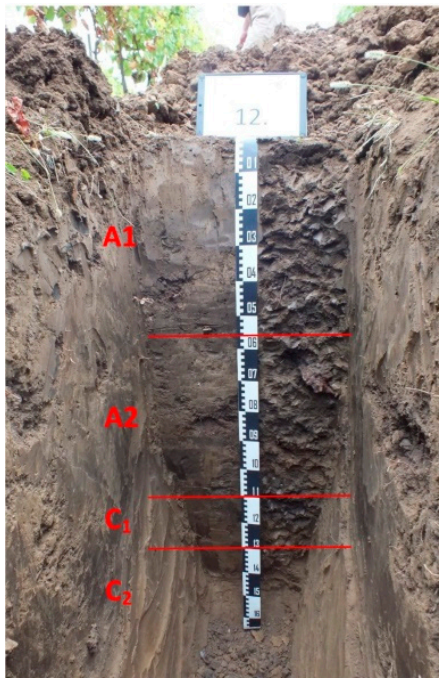

(b)

Figure 4. Soil profiles: (a) Locality Lipovac-Eutric Cambisol (Clayic), (CM-eu-ce). (b) Locality Gornje Zleginje-Haplic Vertisol, (VR-ha).

Soil profiles were analyzed at 16 representative locations, up to a maximum depth of $200 \mathrm{~cm}$ or to the parent material. Samples were taken in undisturbed (Kopecký cylinders, volume $100 \mathrm{~cm}^{3}$ ) and disturbed state using an Eijkelkamp percussion core sampler. The total number of this soil samples was 116. Field work took place during 2015.

Georeferencing of soil and parcel samples in this study was performed using GPS receivers (Trimble GPS GeoXH 3000, Trimble GPS Juno SC, Terrasync Professional software; Trimble, Inc., Sunnyvale, CA, USA). Data processing was carried out using the ESRI ArcEditor 10 GIS (geographic information system).

The initial SOC state of vineyards was obtained from the soil analysis before vineyards establishment, since 1975.

\subsection{Fertilization Strategies}

The fertilization strategies in the observed vineyards are given in Table 2. These data are derived from long-term management records for the period 1975-2015. 
Table 2. The fertilization strategies in the observed vineyards.

\begin{tabular}{ll}
\hline AF + FM + NPK & $\begin{array}{l}\text { Ameliorative fertilization initially + farmyard manure initially } \\
+ \text { continuous application of NPK }{ }^{1} \text { inorganic fertilizers }\end{array}$ \\
\hline AF + NPK & $\begin{array}{l}\text { Ameliorative fertilization initially + continuous application of } \\
\mathrm{NPK}^{1} \text { inorganic fertilizers }\end{array}$ \\
\hline $\mathrm{AF}+\mathrm{FM}$ & Ameliorative fertilization initially + farmyard manure initially \\
\hline $\mathrm{FM}+\mathrm{GM}$ & Farmyard manure initially + green manure continuously \\
\hline $\mathrm{F}$ & Foliar microbial fertilizer continuously \\
\hline $\mathrm{NF}$ & No fertilizers \\
\hline
\end{tabular}

\subsection{Laboratory Analysis}

All laboratory analyses were performed at the Laboratory for Soil and Agroecology of the Institute of Field and Vegetable Crops, accredited according to the standard ISO/IEC 17025:2017 [38].

The soil samples collected were naturally air-dried, milled and passed through a $2.0 \mathrm{~mm}$ sieve, according to ISO 11464:2006 [39]. Soil pH value was determined by the potentiometric method according to ISO 10390:2005 [40] in a 1:5 suspension of soil in $1 \mathrm{M} \mathrm{KCl}$ using a Mettler Toledo SevenCompact $\mathrm{pH}$ meter with glass electrode (Mettler Toledo, LLC, Columbus, OH, USA). The carbonate content ( $\mathrm{as}^{\left.\mathrm{CaCO}_{3}\right)}$ was determined according to the ISO 10693:1995 [41] volumetric method. SOC was determined by elementary analysis using CHNSO VarioEL III Elementar (Elementar Analysensysteme GmbH, Langenselbold, Germany) after dry combustion and carbonate removal, in accordance with the ISO 10694:1995 [42]. The particle size distribution was determined in the $<2 \mathrm{~mm}$ fraction using the pipette method [43]. The size fractions were defined as clay $(<2 \mu \mathrm{m})$, silt $(2-20 \mu \mathrm{m})$, fine sand $(20-200 \mu \mathrm{m})$ and coarse sand $(200-2000 \mu \mathrm{m})$.

Bulk density (BD) was determined from standard volume (Kopecký cylinders; $100 \mathrm{~cm}^{3}$ ) soil samples, which were dried to constant mass at $105^{\circ} \mathrm{C}$.

\subsection{Calculation of SOC Stocks}

Soil organic carbon stocks were calculated:

$$
\operatorname{SOC}\left(\mathrm{t} \mathrm{C} \mathrm{ha}^{-1}\right)=\operatorname{SOC}(\%) \times \operatorname{BD}\left(\mathrm{g} \mathrm{cm}^{-3}\right) \times \operatorname{SLT}(\mathrm{cm}) \times[1-(\mathrm{GV} / 100)]
$$

where BD—bulk density; SLT—soil layer thickness; GV—gravel volume (\%).

\subsection{Statistical Analyses}

Study data were processed by the methods of descriptive statistics. The effects of fertilizer strategies and soil type on SOC were estimated by an analysis of variance (ANOVA). The significances of the differences were determined using the Duncan's range test (multistage test) $(p<0.05)$. Regression analysis was used for estimating the relationships between soil depth and SOC content. Correlation analysis was calculated by using the Pearson correlation at a significance level of $p<0.05$. All statistical analyses were performed using STATISTICA 12.6 (StatSoft, Inc. Corporation, Tulsa, OK, USA).

\section{Results and Discussion}

\subsection{Characteristics of the Soil}

Physical and chemical soil properties of the examined vineyards for the soil layers $0-30 \mathrm{~cm}, 30-60 \mathrm{~cm}$ and profile horizons $(<200 \mathrm{~cm})$ are given in Table 3. Soil $\mathrm{pH}$ value was highly acid to alkaline in topsoil and subsoil, according to classification for vineyard soils [44]. The topsoil layer $(0-30 \mathrm{~cm})$ has an acidic $\mathrm{pH}$ value for the most part $(72 \%$ of the region's surface area). In the soil profile horizons, the $\mathrm{pH}$ value of most soils increased with 
depth. The most suitable soil $\mathrm{pH}$ in terms of vine cultivation is neutral [45]. According to White [46] the optimum $\mathrm{pH}$ range for vine growth is 5.5-8. Slightly acidic and neutral vineyard soils generally have better nutrient balance for plant growth. Soil $\mathrm{pH}$ value is most often a natural property of the soil and comes from the $\mathrm{pH}$ reaction of the parent substrate in which the soil was formed.

Table 3. Descriptive statistics of soil properties in layers $0-30,30-60 \mathrm{~cm}$ and profile horizons $(<200 \mathrm{~cm})$.

\begin{tabular}{|c|c|c|c|c|}
\hline Soil Properties & Min. & Max. & Mean & Std. Dev. \\
\hline \multicolumn{5}{|c|}{$0-30 \mathrm{~cm}$} \\
\hline $\mathrm{pH}$ (in $1 \mathrm{M} \mathrm{KCl}$ ) & 3.94 & 7.60 & 5.53 & 1.14 \\
\hline $\mathrm{CaCO}_{3}(\%)$ & 0.00 & 18.45 & 1.29 & 2.87 \\
\hline Clay $(\%)$ & 17.76 & 50.48 & 38.81 & 6.33 \\
\hline Silt (\%) & 16.36 & 32.36 & 25.48 & 3.70 \\
\hline Fine sand $(\%)$ & 19.83 & 46.32 & 29.55 & 5.36 \\
\hline Coarse sand $(\%)$ & 1.17 & 19.86 & 6.12 & 4.39 \\
\hline \multicolumn{5}{|c|}{$30-60 \mathrm{~cm}$} \\
\hline $\mathrm{pH}$ (in $1 \mathrm{M} \mathrm{KCl})$ & 3.77 & 7.56 & 5.35 & 1.13 \\
\hline $\mathrm{CaCO}_{3}(\%)$ & 0.00 & 10.90 & 1.38 & 2.72 \\
\hline Clay (\%) & 13.96 & 49.96 & 39.13 & 6.65 \\
\hline Silt (\%) & 15.76 & 33.60 & 25.33 & 3.87 \\
\hline Fine sand (\%) & 20.34 & 47.62 & 29.49 & 5.46 \\
\hline Coarse sand (\%) & 1.16 & 17.66 & 6.05 & 4.40 \\
\hline \multicolumn{5}{|c|}{ profile horizons, $0-200 \mathrm{~cm}$} \\
\hline $\mathrm{pH}$ (in $1 \mathrm{M} \mathrm{KCl}$ ) & 3.75 & 7.47 & 5.61 & 1.25 \\
\hline $\mathrm{CaCO}_{3}(\%)$ & 0.00 & 37.90 & 3.08 & 8.42 \\
\hline Clay (\%) & 15.84 & 54.16 & 40.96 & 8.24 \\
\hline Silt (\%) & 17.20 & 46.16 & 26.34 & 5.22 \\
\hline Fine sand (\%) & 18.91 & 40.71 & 27.12 & 5.50 \\
\hline Coarse sand (\%) & 1.09 & 20.47 & 5.59 & 4.67 \\
\hline Bulk density $\left(\mathrm{g} \mathrm{cm}^{-3}\right)$ & 1.24 & 1.70 & 1.52 & 0.13 \\
\hline
\end{tabular}

Samples of topsoil and subsoil belong to the noncalcareous to highly calcareous soil category [44]. The content of $\mathrm{CaCO}_{3}$ in completely carbonate-free soils is completely uniform in terms of profile depth or a small part of carbonates appears at the lower layer. In other soils, the carbonate content generally increases in depth of the profile. The content of free $\mathrm{CaCO}_{3}$ largely depends on the parent substrate, i.e., the type of soil.

Bulk density (BD) of the soils varied between 1.24 and $1.70 \mathrm{~g} \mathrm{~cm}^{-3}$ (Figure 5). The BD of most of the examined soil profiles increases with depth, as a consequence of the long-term pressure of the upper soil layers on the lower layers. Most of the examined horizons have BD of more compact arable soils, according to the classification of Kačinski [47,48] which is unfavorable from the aspect of water, air and temperature regime of these soils. According to Leake [45] the BD values in the vineyard soils should be less than $1.4 \mathrm{~g} \mathrm{~cm}^{-3}$. In the study of Doğan and Gülser [49], BD of vineyards soils varied between 1.07 and $1.75 \mathrm{~g} \mathrm{~cm}^{-3}$. 


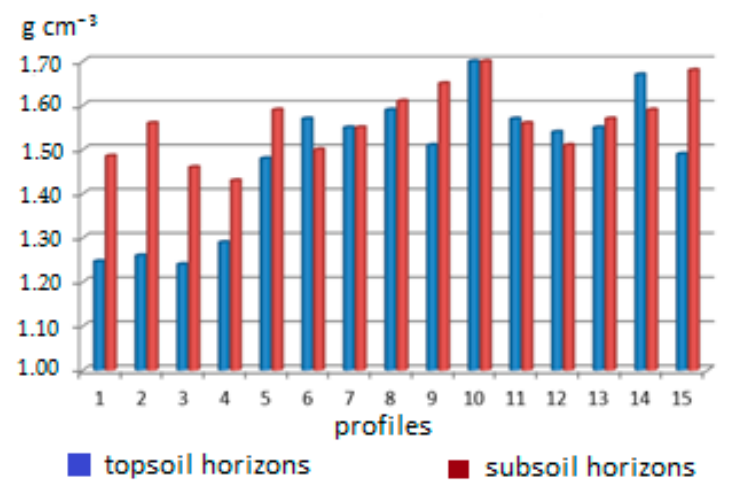

Figure 5. Bulk density of the soil profiles.

The soil texture examined for the Tri Morave wine growing region is characterized by increased clay content (Figure 6). Clay content of vineyard fields varies between 13.96\% and $50.48 \%$. Most of the samples are concentrated in the classes of light clay and heavy clay. This texture is unfavorable for most cultivated plant species. According to Gücüyen, loamy soils include high organic matter, low-water-holding capacity and well-drained characteristics that are generally suitable for good quality grape production [50].

\subsection{Soil Organic Carbon Stock}

The soil organic carbon stock in the organic layer $(0-30 \mathrm{~cm})$ of the observed vineyard soils ranged between 17.72 and $87.04 \mathrm{t} \mathrm{ha}^{-1}$, with mean value $46.19 \mathrm{t} \mathrm{ha}^{-1}$ (Figure 7). In subsoil (30-60 cm), SOC stock ranged between 14.54 and $91.16 \mathrm{t} \mathrm{ha}^{-1}$, with mean value $40.26 \mathrm{t} \mathrm{ha}^{-1}$. These results are lower than the average value for SOC stock of agricultural land in Serbia. The previous analysis of organic carbon content in agricultural land of Serbia showed that in the $0-30 \mathrm{~cm}$ layer, values of SOC stock ranged from 3.72 to $328.23 \mathrm{tha}^{-1}$ with mean value $68.99 \mathrm{t} \mathrm{ha}^{-1}$ [51].

Similar results were obtained by other authors. According to the assessment of the mean SOC stock of the different cropland uses in Italy, SOC stock in the top $30 \mathrm{~cm}$ of mineral soil for the vineyards was $41.9 \pm 15.9 \mathrm{t} \mathrm{ha}^{-1}$ [31]. In his study, SOC stock for the whole cropland category was $52.1 \pm 17.4 \mathrm{tC} \mathrm{ha}^{-1}$, which is in the range of those reported for other European countries. Smith et al. [52] suggest a mean value of $53 \mathrm{tC} \mathrm{ha}^{-1}$ as an average value for all European cropland soils. SOC stocks in peninsular Spain showed a high heterogeneity, with the lowest values in arid regions. The average value in topsoil $(0-30 \mathrm{~cm})$ was $44 \pm 26$ and $57 \pm 35 \mathrm{t} \mathrm{C} \mathrm{ha}^{-1}$ in subsoil $(30-50 \mathrm{~cm})$ [11]. SOC stock in vineyards of peninsular Spain was reported by Murillo [33] at $42.5 \pm 28.9 \mathrm{t} \mathrm{C} \mathrm{ha}^{-1}$. For France, the SOC stock in the agricultural soils was estimated at 15 to $40 \mathrm{t} \mathrm{ha}^{-1}$ in mid-France and 40-50 tha ${ }^{-1}$ in the north and southwest [53]. Results for SOC stocks in the vineyards of France were reported by Martin et al. [32] at $39.4 \pm 26.5 \mathrm{tha}^{-1}$.

Besides the specific soil properties in vineyards, the reduction of SOC is possibly a consequence of the intensification of agricultural practices [54,55]. In the observed area, the management is based on the reduced use of organic fertilizers, which are applied mainly only when establishing vineyards, as well as on conventional land cultivation in intensive production. Intensive viticulture could lead to the soil degradation, with loss of soil fertility, acceleration of soil erosion and $\mathrm{SOM}$ mineralization, and $\mathrm{CO}_{2}$ emission increase $[26,27,56]$. Soil tillage affects soil respiration, temperature, water content, $\mathrm{pH}$, oxidation-reduction potential and the soil ecology $[57,58]$. In particular, it enhances the microbial biomass turnover and, in turn, the short-term $\mathrm{CO}_{2}$ evolution by improving soil aeration, increasing the contact between soil and crop residues and by exposing organic matter to microbial attack [59]. 


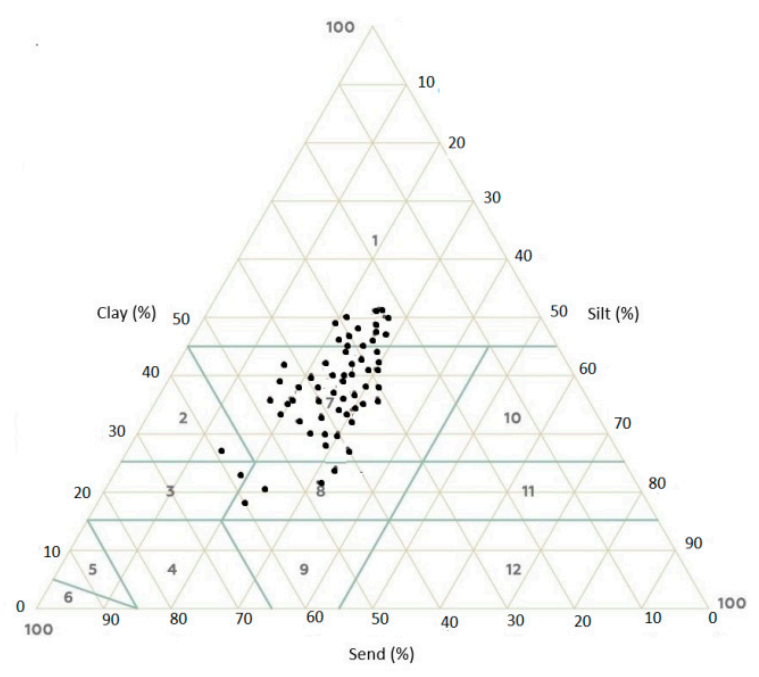

(a)

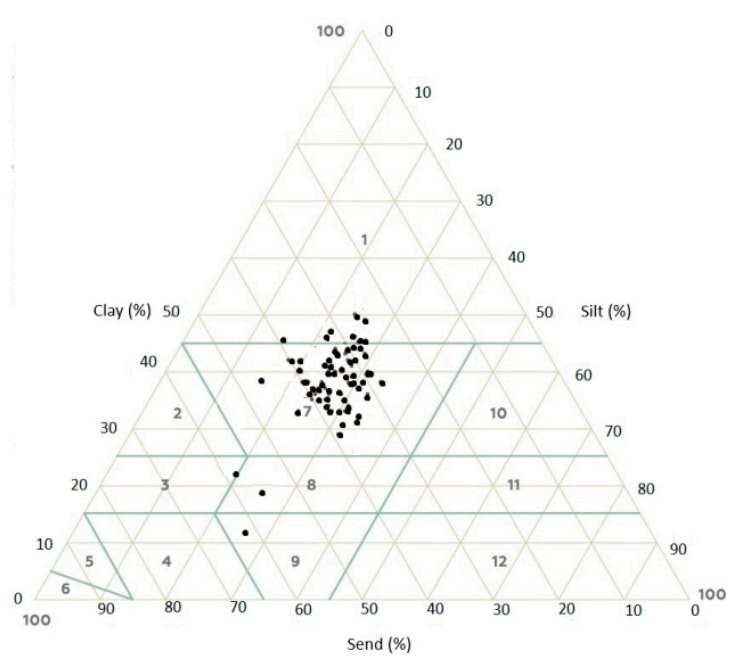

(b)

Figure 6. Textural triangle diagram according to International Union of Soil Sciences (IUSS) system of classification of soil particles: (a) soil depth 0-30 cm ( $\mathrm{N}=56)$ and $(\mathbf{b})$ soil depth 30-60 $\mathrm{cm}(\mathrm{N}=56)$. Textural classes: 1-heavy clay, 2 -sandy clay, 3-sandy clay loam, 4-sandy loam, 5-loamy sand, 6—sand, 7-light clay, 8—clay loam, 9—loam, 10—silty clay, 11—silty clay loam, 12-silt loam.

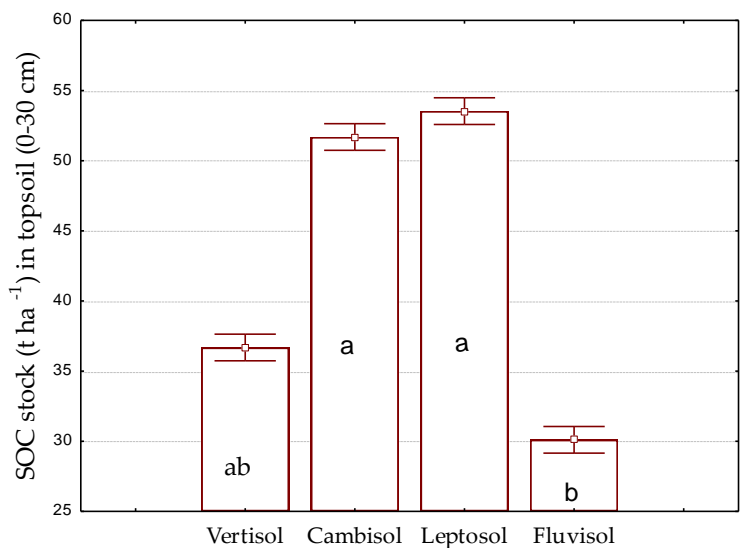

(a)

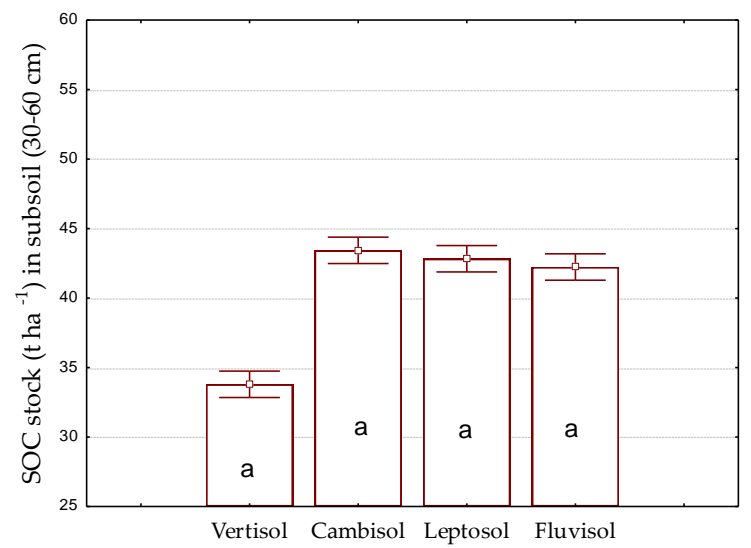

(b)

Figure 7. Soil organic carbon (SOC) stocks: (a) topsoil, 0-30 $\mathrm{cm}(\mathrm{N}=56)$, and (b) subsoil, $30-60 \mathrm{~cm}(\mathrm{~N}=56)$. Significant differences among soil groups are labeled with different letters (Duncan's range test, $p<0.05$ ).

Experiments conducted in the United States [60] show a reduction of more than $30 \%$ in the SOM content in soils that have been cultivated for many years. In the undisturbed state, SOM contents are the result of a balance between mineralization losses and organic matter inputs. Disturbances change this equilibrium very quickly, leading to a higher level of decomposition of SOM, especially the labile forms (sugars, amino acids) that play a major role in stabilizing the physical structures of the soil [51]. The remaining forms of SOM are less effective in stabilizing the soil structure. Such a system is in a state of degradation, which can be prevented by compensating for the loss of SOM by increasing organic matter input.

The results of our study confirmed that different soil types exhibited typical ranges topsoil carbon storage. Lepotsols $\left(53.53 \mathrm{tha}^{-1}\right)$ yielded the highest SOC in topsoil. A similar value was observed in Cambisol (51.69 $\left.\mathrm{t} \mathrm{ha}^{-1}\right)$. The comparison between SOC stocks of Fluvisols (30.11 t ha $\left.{ }^{-1}\right)$ and Vertisols $\left(36.69 \mathrm{t} \mathrm{ha}^{-1}\right)$ revealed no significant differences. A previous assessment of organic carbon stocks in the agricultural soils of the Republic of 
Serbia [51] observed the following mean values for the reference soil groups: Leptosols $\left(151.33 \mathrm{t} \mathrm{ha}^{-1}\right)$, Cambisols $\left(89.81 \mathrm{t} \mathrm{ha}^{-1}\right)$, Vertisols $\left(71.09 \mathrm{t} \mathrm{ha}^{-1}\right)$ and Fluvisols (70.80 $\mathrm{t}$ $\mathrm{ha}^{-1}$ ). In this study, the mean values of SOC for observed soil type were higher than our results, but of the same order. In soils of the Vojvodina region, the largest SOC stocks were observed in Vertisols $\left(74 \mathrm{t} \mathrm{ha}^{-1}\right)$ and the lowest Fluvisol $\left(46 \mathrm{tha}^{-1}\right)$ [61]. Murillo [33] reported mean values of SOC stocks for peninsular Spain: $71.4 \pm 57.8 \mathrm{tC}^{-1}$ for Cambisols; $75.8 \pm 58.9 \mathrm{t} \mathrm{C} \mathrm{ha}^{-1}$ for Fluvisol; $98.8 \pm 56.4 \mathrm{t} \mathrm{C} \mathrm{ha}^{-1}$ for Leptosol and 68.9 $\pm 37.8 \mathrm{t} \mathrm{C} \mathrm{ha}^{-1}$ for Vertisol. It may be concluded that SOC stocks in all of the observed soil types for vineyards were lower than the average for agricultural land in Serbia.

The highest SOC in subsoil were for Cambisols $\left(43.43 \mathrm{tC} \mathrm{ha}^{-1}\right)$. Fluvisols $\left(42.23 \mathrm{tC} \mathrm{ha}^{-1}\right)$ and Lepotsols ( $42.83 \mathrm{tC} \mathrm{ha}^{-1}$ ) revealed similar SOC stocks in the soil horizon. The subsoil of Vertisols yielded the lowest amount of SOC $\left(33.79 \mathrm{t} \mathrm{ha}^{-1}\right)$. The differences in SOC stocks of all soil groups in subsoils were not significant. Fluvisol contain much higher SOC stocks in subsoils than in topsoil. Schöning et al. [62] highlighted the importance of subsoil carbon balance on a plot scale. Grüneberg [63] showed that this is also true for the regional scale.

Differences of SOC stocks can be partly explained by soil texture, which is a result of different parent materials on which the soils developed. Cambisols are characterized by adequate profile depth, good texture and water-air properties. Fluvisols are formed due to the constant deposition of fresh suspensions and do not have a developed humus horizon. The humus content is low, about $2 \%$, and often below $1 \%$, and it is not distributed uniformly in depth. These characteristics can explain our results. The high concentration of SOC in Leptosols is a consequence of the humus layer in humus-carbonate and humussilicate soils. Lower regions under natural vegetation contain $5-10 \%$ of humus, while higher ones can contain up to $20 \%$ [64]. Vertisols have low production value due to the high clay content and specificity of descending material from upper to lower layers due to the formation of cracks during the dry part of the year.

\subsection{Organic Carbon Concentrations in Observed Soil Types}

The mean SOC concentrations in the topsoil and subsoil of the observed soil types of the Tri Morave vineyard region are given in Table 4. The highest mean concentration of SOC in topsoil was found in Leptosols and Cambisols, and the lowest in Fluvisols. As for the SOC stocks, the organic carbon concentration in the agricultural soils was also lower in our results than in the previous assessment for the reference soil groups [51], in which the content ranged from $0.08 \%$ to $21.72 \%$, with a mean value of $2.07 \%$ for the top $30 \mathrm{~cm}$. In this study, Vertisols $(1.76 \%)$ and Fluvisols $(1.74 \%)$ were characterized as soils of low SOC concentration, while Leptosols (3.96\%) and Cambisols (2.16\%) belonged to the class with medium SOC contents.

Table 4. SOC concentrations (\%) in soil layers at 0-30 and 30-60 cm ( $=112)$.

\begin{tabular}{lcccc}
\hline Soil Type & Min. & Max. & Mean & Std. Dev. \\
\cline { 2 - 5 } & \multicolumn{5}{c}{$0-30 \mathrm{~cm}$} \\
\hline Eutric Cambisol & 0.64 & 2.02 & 1.12 & 0.32 \\
Haplic Vertisol & 0.38 & 1.19 & 0.85 & 0.32 \\
Skeletic Leptosol & 0.94 & 1.25 & 1.12 & 0.16 \\
Gleyic, Skeletic Fluvisol & 0.62 & 0.73 & 0.67 & 0.07 \\
\hline & \multicolumn{5}{c}{$30-60 \mathrm{~cm}$} \\
\hline Eutric Cambisol & 0.31 & 1.15 & 0.93 & 0.32 \\
Haplic Vertisol & 0.38 & 1.03 & 0.74 & 0.32 \\
Skeletic Leptosol & 0.74 & 1.00 & 0.89 & 0.13 \\
Gleyic, Skeletic Fluvisol & 0.52 & 1.14 & 0.83 & 0.43 \\
\hline
\end{tabular}

In the examination of SOC concentration of European soils, for all soil categories (arable, forest, grass and others) the following values were obtained: Cambisols 2.4\%, 
Fluvisols 1.6\% and Vertisols 1.5\% [16]. In the experiment of Novara et al. [25], which was carried out on a flat vineyard area in the west of Sicily, Italy, on calcic-gleyic vertisol, SOC content was $0.95 \pm 0.07 \%$, similar to our results.

The overall mean SOC concentration of the samples in topsoil $(0-30 \mathrm{~cm}), 1.02 \pm 0.32 \%$, was higher than the SOC concentrations in subsoil $(30-60 \mathrm{~cm}), 0.85 \pm 0.32 \%$.

In the deeper layers, the SOC concentration was fairly uniform. The highest SOC content was also recorded in Cambisols, while the lowest was found in Vertisols.

Numerous studies reported a dominant effect of soil type on SOC stocks both in topsoil and subsoil $[22,24,65]$. Soil type is strongly associated with SOC storage at multiple scales and under different climatic conditions [66]. Soil type is not an independent control factor but integrates climate, parent material and topography related properties, which affect the potential of soils to store $C$, particularly through moisture regime and texture [66].

\subsection{Distribution of Organic Carbon in the Soil Profile}

The SOC content in soil profile horizons ranged from $0.09 \%$ to $1.79 \%$ (Figure 8 ). The highest SOC content was observed in the topsoil layer, as expected. This is a consequence of the accumulation of organic matter originating from plant residues, as well as higher activity of microorganisms, which participate in the decomposition of fresh organic matter. Significant factors in these processes are soil temperature and humidity.

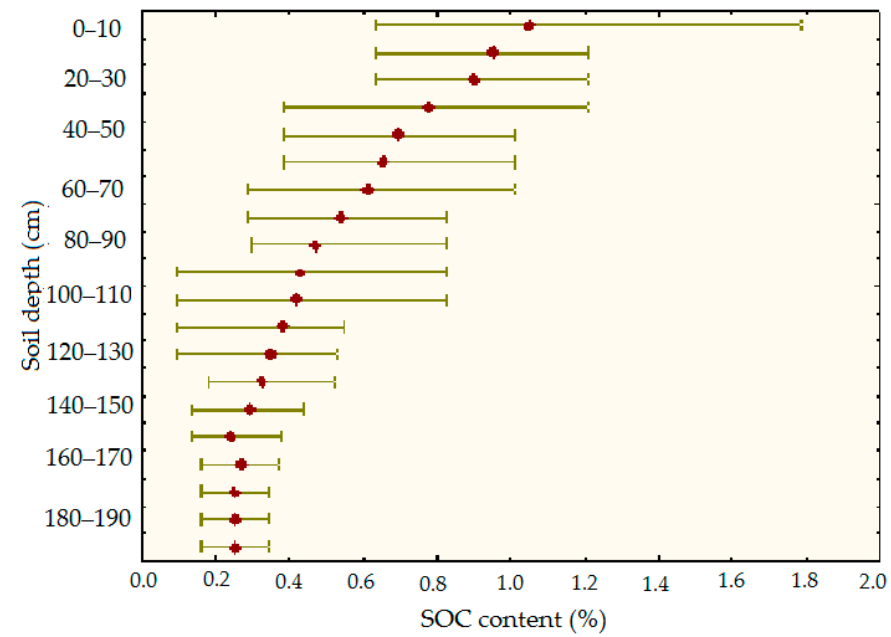

Figure 8. Vertical distribution of soil organic carbon (SOC) content in soil profile of vineyards, $<200 \mathrm{~cm}$ $(\mathrm{N}=60)$.

The average value of SOC decreased rapidly with increasing depth, which is in agreement with the results of other research [67-69]. Regression analysis revealed a statistically significant change in SOC content with soil depth (Figure 9). The average SOC content decreased by $0.62 \%$ in the $0-100 \mathrm{~cm}$ layer with increasing depth. The declining trend of SOC content decreases in the deeper layer, 100-200 cm, with the average SOC value falling by $0.17 \%$. 


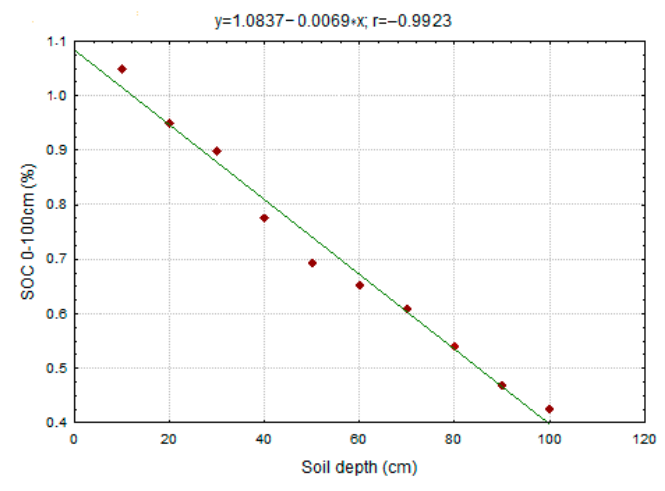

(a)

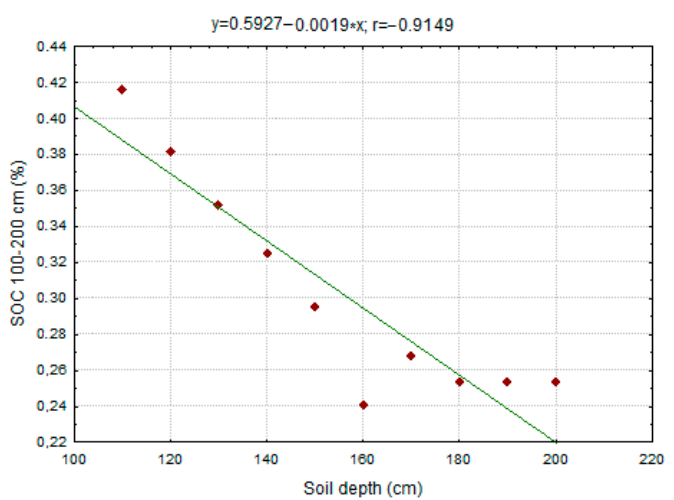

(b)

Figure 9. Regression analysis for the relationships between soil depth and SOC content in the soil profile of vineyards (<200 cm): (a) soil depth 0-100 cm and (b) soil depth 100-200 cm.

In the study by Yu et al. [67], the mean value of SOC in the $0-100 \mathrm{~cm}$ soil layer decreased rapidly with increasing soil depth, ranging from $3.37 \pm 1.43 \mathrm{~g} \mathrm{~kg}^{-1}$ in the topsoil layer $(0-20 \mathrm{~cm})$ to $1.66 \pm 0.98 \mathrm{~g} \mathrm{~kg}^{-1}$ in the $80-100 \mathrm{~cm}$ layer.

Correlation analysis showed a more significant correlation between SOC and soil depth in the upper layer $(r=0.99)$ compared to the deeper soil layer $(r=0.91)$.

\subsection{Effect of Fertilization Strategies on SOC Concentration}

Fertilizer management is important for increasing crop productivity and soil quality, while limiting the environmental contamination. In intensive vineyard production of Serbia, fertilization is mostly based on inorganic fertilizers. Some winegrowers avoid using organic amendments, because they fear negative effects on the quality of the grapes (extended period of grape ripening, low sugar and high acid content). However, several studies confirmed that the combined application of mineral and organic fertilizers give the best results in terms of grape yield $\left(4.7 \mathrm{~kg}\right.$ vine $\left.^{-1}\right)$ and the physical and chemical characteristics of bunches and berries (14.72\% sugar) [70,71]. Only individual application of organic fertilizers led to the lower yield $\left(3.6 \mathrm{~kg}\right.$ vine $\left.^{-1}\right)$ [70,72] and lower content of sugar in berries $(14.29 \%)$ [70,73], as well as to the increase in berry acidity $\left(4.32 \mathrm{~g} \mathrm{~L}^{-1}\right)$ [70]. The overall polyphenol concentration is higher in organic grapes, resulting in a higher protection from oxidation [72]. The fertilization practice, based on exclusively inorganic fertilizers, could jeopardize soil quality and content of SOC.

Table 5 shows the SOC concentration in vineyards with different fertilization strategies. Combining ameliorative fertilization and application of farmyard manure initially with continuous application of NPK inorganic fertilizers has led to the highest SOC. In relation to the plots where no fertilizer was applied, the SOC content was increased by $0.37 \%$, while in relation to the application of foliar fertilizer only, it was increased by $0.27 \%$. These differences were statistically significant, while there were no statistically significant differences compared to the other variants. Similar results were obtained by other authors. Yang et al. [74] indicated that the SOC content could be maintained at a relatively stable level under sufficient chemical fertilizer application without return of manure and crop residue conditions, and SOC content was increased with the combination of chemical fertilizer and manure application. 
Table 5. Influence of different fertilization strategies on SOC concentrations (\%) of vineyards $(0-30 \mathrm{~cm}$ and $30-60 \mathrm{~cm}$ ).

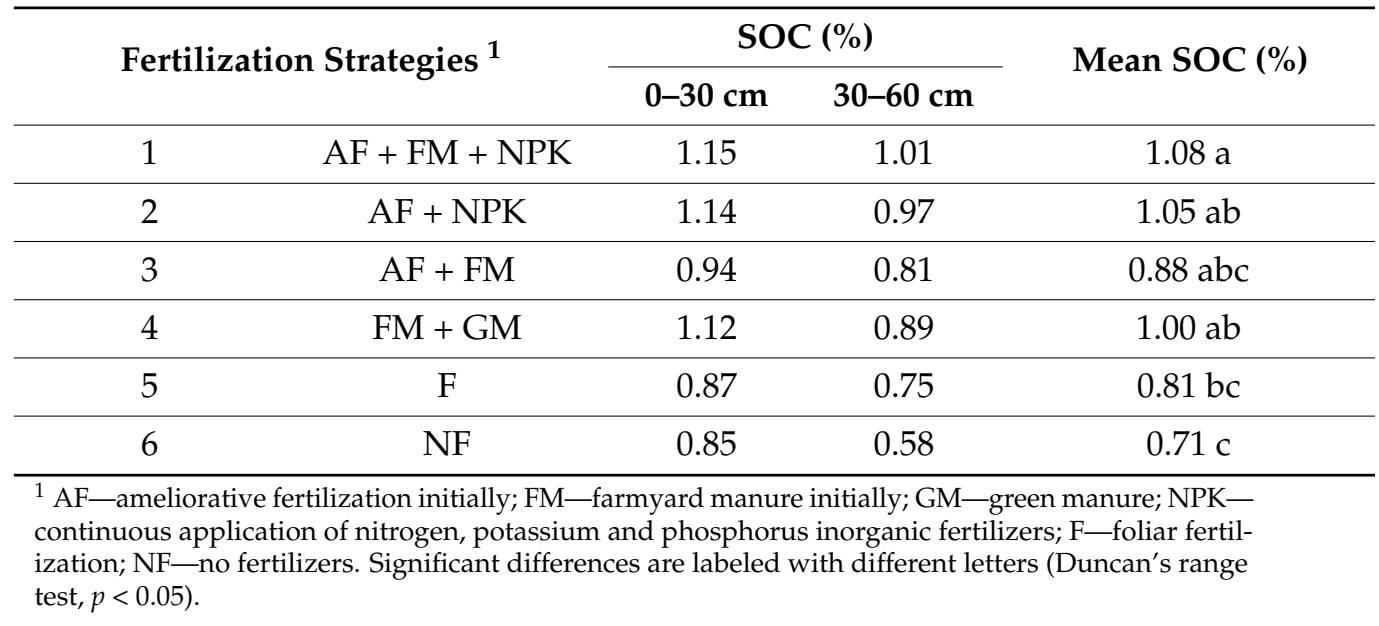

Application of AF + NPK led to the SOC concentration that was statistically significantly higher than in the variant without fertilization, by $0.34 \%$. Similar results were obtained by application of FM + GM, where SOC was increased by $0.29 \%$, compared to the NF. There were no statistically significant differences compared to other variants.

The lowest SOC content was recorded on plots that had not been fertilized at all, as well as those that had been fertilized with only foliar fertilizer. Similar results were observed by Liu et al. [75]. Hao et al. [76] stated that the effects of manure application, tillage, crop rotation, fertilizer rate, and soil and water conservation farming have positive influence on the SOC pool. They found that SOC at the $0-15 \mathrm{~cm}$ soil layer was $6.2 \%, 7.7 \%$ and $9.3 \%$ higher with manure, chemical fertilizers and manure plus fertilizers, respectively, than with no fertilizer application.

Between the vineyard establishment and 2015, the mean SOC concentration decreased in both depths of unfertilized vineyards (Table 6). In fertilized vineyards, SOC decreased only in topsoil. In this, the shallow layer, tillage significantly affects soil respiration, temperature, water content and other soil properties. The contact between soil and crop residues increases and organic matter is more exposed to microbial attack. This leads to a decrease in the content of SOC.

The reduction of SOC was rapid in the earlier stage of cultivation. Similar results were obtained by other authors. Liu et al. [75] showed a significant decline of total SOC that occurred in the first five years of cultivation where the average SOC loss per year was about $2.3 \mathrm{t} \mathrm{ha}^{-1}$ for the $0-17 \mathrm{~cm}$ horizon. The average annual SOC loss between 5- and 14-year cultivation was $0.95 \mathrm{t} \mathrm{ha}^{-1}$ and between 14- and 50-year cultivation it was $0.29 \mathrm{t} \mathrm{ha}^{-1}$. Compared with the uncultivated soil, Liu et al. also indicated that SOC loss (the sum of three horizons) was $17 \%, 28 \%$ and $55 \%$ in the 5 -, 14 - and 50 -year cultivation periods, respectively. Biddoccu et al. [77] found that average soil loss in a mountain vineyard, Aosta valley (NW Italy), was $15.7 \mathrm{t} \mathrm{ha}^{-1} \mathrm{y}^{-1}$. The loss of the SOC could be reduced by taking into account some of the different mitigation options, such as manuring and fertilizing, conservation tillage, management of crop residues and cover cropping [54,78,79]. 
Table 6. Soil organic carbon change in vineyards between the establishment and 2015.

\begin{tabular}{|c|c|c|c|c|c|c|c|}
\hline \multirow[t]{2}{*}{$\begin{array}{l}\text { Fertilization } \\
\text { Strategies }\end{array}$} & \multirow[t]{2}{*}{$\begin{array}{l}\text { Years of } \\
\text { Cultivation }\end{array}$} & \multicolumn{2}{|c|}{$\begin{array}{l}\text { SOC Concentration } \\
\text { Change }\left(\mathrm{g} \mathrm{kg}^{-1} \mathrm{y}^{-1}\right)\end{array}$} & \multicolumn{2}{|c|}{$\begin{array}{c}\text { SOC Stock Change (t } \\
\left.h^{h a^{-1}} y^{-1}\right)\end{array}$} & \multicolumn{2}{|c|}{$\begin{array}{l}\text { Rate of SOC Stock } \\
\text { Change }\left(\% \mathrm{y}^{-1}\right)\end{array}$} \\
\hline & & $0-30 \mathrm{~cm}$ & $30-60 \mathrm{~cm}$ & $0-30 \mathrm{~cm}$ & $30-60 \mathrm{~cm}$ & $0-30 \mathrm{~cm}$ & $30-60 \mathrm{~cm}$ \\
\hline $\mathrm{NF}$ & $\leq 5$ & -0.77 & -1.15 & -3.61 & -5.21 & -8.42 & -10.21 \\
\hline \multirow{2}{*}{$\mathrm{IF}+\mathrm{FM}$} & $\leq 5$ & -1.66 & 0.47 & -6.75 & 2.01 & -13.29 & 6.00 \\
\hline & $6-40$ & -0.10 & 0.10 & -0.42 & 0.43 & -0.64 & 1.17 \\
\hline
\end{tabular}

${ }^{1} \mathrm{NF}$-no fertilizers, IF-inorganic fertilizers continuously, FM-farmyard manure initially.

The reduction of SOC in topsoil of fertilized vineyards, in the first five years, was higher compared to the unfertilized plots. The reason is initially higher concentration of SOC in fertilized vineyards. Similar results were obtained Garcia-Diaz et al. [80]. They stated that the decrease in SOC content after tillage was greater in the treatment that presented higher SOC content.

The SOC content increased in subsoil of vineyards that had been fertilized initially with sufficient amounts of inorganic fertilizer during the cultivation and farmyard manure. The deep tillage $(60-80 \mathrm{~cm})$ has led to deep placement of organic amendments and equalization of SOC content between the mixed layers. On average, even 35 years after deep tillage event, the subsoil still contained $13.49 \mathrm{t} \mathrm{ha}^{-1}$ more SOC than before this measure. It can be concluded that deep tillage can preserve SOC in the deeper soil layer and prevent carbon loss from the surface layer. Subsoil holds a large potential to store additional soil organic carbon (SOC) because of the large number of unsaturated mineral surfaces and environmental conditions that impede SOC decomposition, e.g., more constant moisture and temperature regime or oxygen limitation [81]. Similar results were obtained by other authors. According to Liu et al. [75], deep tillage (subsoiling) increased SOC and N relative to conventional tillage. Cervantes et al. [81] stated that after the deep plowing event, the layer of the deeply plowed fields accumulated on average $0.4 \pm 0.1 \mathrm{Mg} \mathrm{SOC} \mathrm{ha}^{-1} \mathrm{yr}^{-1}$.

Similar results were stated by Liu et al. [75] with the rotary plowing and conventional tillage, where the SOC contents at $16-30 \mathrm{~cm}$ were higher than in the depth between 0 and $15 \mathrm{~cm}$, indicating that more root residues were incorporated into this layer. This result was consistent with mixing of organic matter by plowing, but opposite to results with no-tillage practice or conservation tillage [82-84]. According to Campbell et al. [85], SOC gains under no-till were about $250 \mathrm{~kg} \mathrm{ha}^{-1} \mathrm{yr}^{-1}$ greater than for tilled systems, regardless of cropping frequency. Within the surface $7.5 \mathrm{~cm}$, the no-till system possessed significantly more SOC (by $7.28 \mathrm{tha}^{-1}$ ) relative to the conventional tillage [86].

\subsection{Correlation of SOC with Soil Properties}

The dependence of SOC content and other physical and chemical properties of soil was examined by correlation analysis and shown in Figure 10. A statistically significant correlation was found only in the lower undisturbed soil layers. In the upper layer, there was a significant decrease in the SOC content and disturbance of the ratio of SOC and other soil properties due to the strong anthropogenic impact. A significant positive correlation of SOC with clay content was found. The positive relationship between clay content and SOC confirmed the global relation between them [87-89]. The fine fraction of soil serves as a measure for SOC storage [66]. Smaller particle size has better water retention, fertilizer retention capacity and higher nutrient content [67]. The stability of SOC is determined by the chemical nature of SOM, absorption in the mineral part of the soil and its participation in the formation of structural microaggregates [90]. With an increased content of clay particles, the content of SOC tends to increase. The reason for this is the bond between the surface of the clay particles and OM, which slows down the decomposition process. Soils with higher clay content increase the potential for aggregate formation [51]. 
Macroaggregates physically protect organic molecules from further mineralization caused by microorganisms [91]. In similar climatic conditions, the SOM content in fine-textured (clay) soils is two to four times higher than in coarse-textured (sandy) soils [92]. The low clay content of the soil tends to be poor in soil aggregation stability and water holding, due to low cohesion forces between elementary particles that affect the porosity [6].
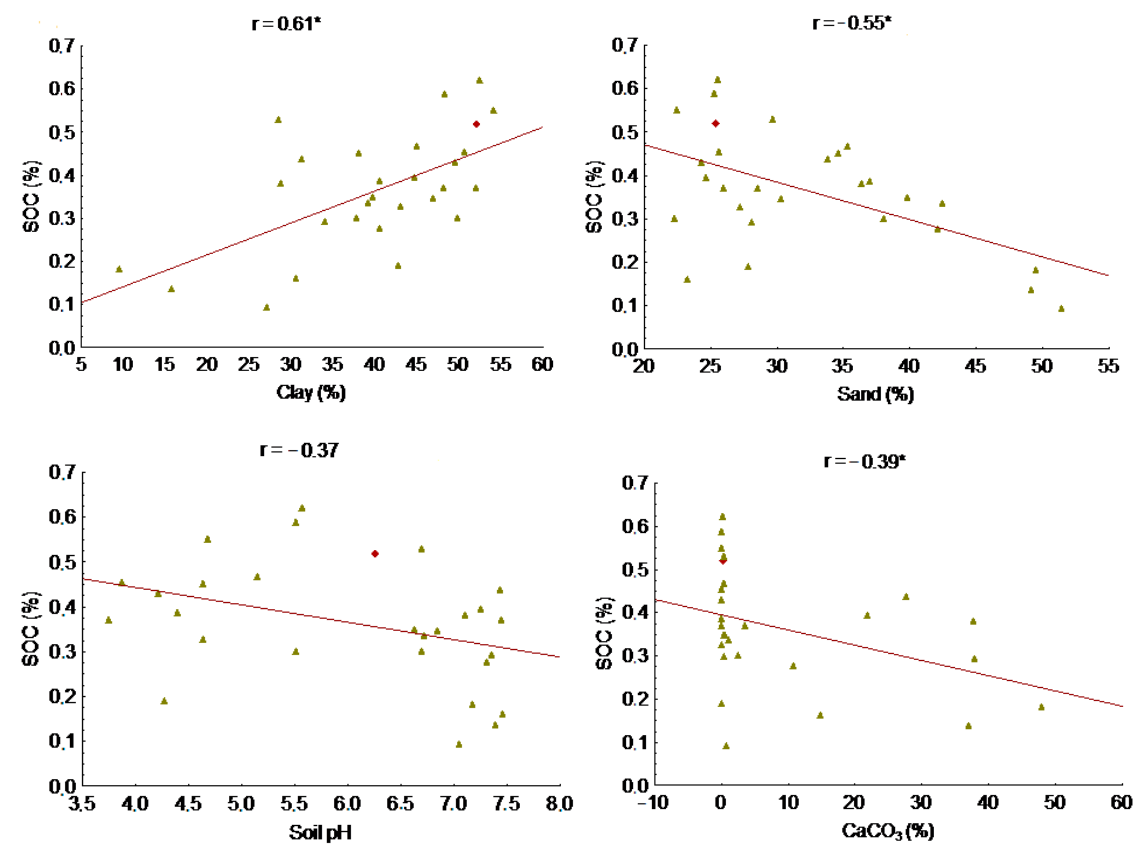

Figure 10. Correlation of SOC with soil properties: clay, sand, $\mathrm{CaCO}_{3}$ content and $\mathrm{pH}$ value, in subsoil layers $(>60 \mathrm{~cm})$ of vineyards; ${ }^{*} p<0.05$.

Sand content was significantly negatively correlated with SOC content, which agrees with the results of Li et al. [93]. They concluded that increasing desertification would reduce the accumulation of SOC. Sandy soils usually contain less SOM than soils with a finer texture, such as loam or clay. Lower moisture content and higher aeration in sandy soils results in faster SOM oxidation compared to heavier soils. In general, poorly drained soils have a higher moisture content and poorer aeration. This results in a higher organic matter $(\mathrm{OM})$ content in these soils than in their better-drained equivalents [51].

SOC content decreased with increasing $\mathrm{pH}$ and $\mathrm{CaCO}_{3}$ content. Negative correlation between $\mathrm{pH}$ value and SOC was found in the study of Islam et al. [94], especially in the presence of high sand percentage and high concentrations of $\mathrm{Na}^{+}$. Similar results were obtained by Ayaz et al. [95]. In their examination, the soil organic carbon stock negatively correlated with soil $\mathrm{pH}(\mathrm{r}=-0.38, p \leq 0.05)$ and calcium carbonate $(\mathrm{r}=-0.45$, $p \leq 0.01)$. Increase of the calcium carbonate concentration and soil $\mathrm{pH}$ significantly affect soil microbial activity and reduces the SOC quantity by the enhancement in the rate of mineralization.

\section{Conclusions}

Intensive viticulture without adequate continuous application of fertilizers combined with organic amendments leads to decreasing of SOC in topsoil of the vineyard. The SOC stock in the topsoil and subsoil of vineyards was lower than the average value for agricultural land in Serbia. The soil type was an important predictor of carbon storage in topsoil.

More efficient management is necessary to increase SOC. The return of crop residues and application of manure or other organic fertilizers could be combined into a management system to prevent the decrease of SOC, but questions arise about the effect of these practices on grape yields and quality, as well as acceptability by farmers. Systematic 
monitoring and more research of long-term SOC change is needed to evaluate the effect of different fertilization strategies on the on the SOC state in vineyards.

Deep tillage has the potential to increase SOC, but the investigation into SOC storage capacity and strategies for effective deep tillage management are necessary.

Soil conservation measures, such as cover crops, conservation buffers, drainage terraces, conservation tillage etc., should be considered for improving the vineyard management.

Supplementary Materials: The following are available online at https:/ / www.mdpi.com/2073-439 5/11/1/9/s1, Figure S1: Some of observed vineyards in the Tri Morave region.

Author Contributions: Conceptualization, S.J. and J.N.; methodology, S.J., J.N. and J.V.; formal analysis, S.J.; investigation, S.J., J.N., D.J., M.Ž., S.M., D.B. and J.V.; data curation, S.J., M.Ž., D.B., D.J. and S.M.; writing — original draft preparation, S.J.; writing-review and editing, S.J.; review and editing, J.N. All authors have read and agreed to the published version of the manuscript.

Funding: This research is part of the project "Characterization of Vineyard Soils for the Designation of Geographical Origin of Wine of the Three Morava Viticulture Region" funded by Ministry of Agriculture, Forestry and Water Management, Directorate for Agricultural Land. A part of this research was supported by the Ministry of Education, Science and Technological Development of the Republic of Serbia, grant number: 451-03-68/2020-14/200032.

Institutional Review Board Statement: Not applicable.

Informed Consent Statement: Not applicable.

Conflicts of Interest: The authors declare no conflict of interest. The funders had no role in the design of the study; in the collection, analyses, or interpretation of data; in the writing of the manuscript, or in the decision to publish the results.

\section{References}

1. Fang, H.J.; Yang, X.M.; Zhang, X.P.; Liang, A.J. Spatial heterogeneity and pattern of black soil organic carbon of sloping field. Bull. Soil Water Conserv. 2005, 25, 20-24.

2. Zhao, J.; Meng, K.; Sui, Y.Y.; Han, B.J.; Zhang, Y.; Li, H.W. Analysis for spatial heterogeneity of organic carbon and available nutrients in black soil region of Hailun county. Chin. J. Soil Sci. 2005, 36, 487-492.

3. Bauer, A.; Black, A.L. Quantification of the Effect of Soil Organic Matter Content on Soil Productivity. Soil Sci. Soc. Am. J. 1994, 58, 185-193. [CrossRef]

4. Loveland, P. Is There a Critical Level of Organic Matter in the Agricultural Soils of Temperate Regions: A Review. Soil Tillage Res. 2003, 70, 1-18. [CrossRef]

5. Campos, R.; Gabrielle, F.P.; Marcos, H.C. Soil Carbon Sequestration in Rainfed and Irrigated Production Systems in a New Brazilian Agricultural Frontier. Agriculture 2020, 10, 156. [CrossRef]

6. Arunrat, N.; Praeploy, K.; Sukanya, S.; Ryusuke, H. Soil Organic Carbon in Sandy Paddy Fields of Northeast Thailand: A Review. Agronomy 2020, 10, 1061. [CrossRef]

7. Kumputa, S.; Vityakon, P.; Saenjan, S.; Lawongsa, P. Carbonaceous Greenhouse Gases and Microbial Abundance in Paddy Soil under Combined Biochar and Rice Straw Amendment. Agronomy 2019, 9, 228. [CrossRef]

8. Gelaw, A.M.; Singh, B.R.; Lal, R. Soil Organic Carbon and Total Nitrogen Stocks under Different Land Uses in a Semi-Arid Watershed in Tigray, Northern Ethiopia. Agric. Ecosys. Environ. 2014, 188, 256-263. [CrossRef]

9. Tashi, S.; Singh, B.; Keitel, C.; Adams, M. Soil Carbon and Nitrogen Stocks in Forests along an Altitudinal Gradient in the Eastern Himalayas and a Meta-Analysis of Global Data. Glob. Chan. Biol. 2016, 22, 2255-2268. [CrossRef]

10. Lal, R. Sequestering Carbon in Soils of Agro-Ecosystems. Food Policy 2011, 36, S33-S39. [CrossRef]

11. Calvo de Anta, R.; Luís, E.; Febrero-Bande, M.; Galiñanes, J.; Macías, F.; Ortíz, R.; Casás, F. Soil Organic Carbon in Peninsular Spain: Influence of Environmental Factors and Spatial Distribution. Geoderma 2020, 370, 114365. [CrossRef]

12. Eswaran, H.; Van Den Berg, E.; Reich, P. Organic Carbon in Soils of the World. Soil Sci. Soc. Am. J. 1993, 57, 192-194. [CrossRef]

13. Batjes, N.H. Total Carbon and Nitrogen in the Soils of the World. Eur. J. Soil Sci. 2014, 65, 10-21. [CrossRef]

14. Jobbágy, E.G.; Jackson, R.B. The vertical distribution of soil organic carbon and its relation to climate and vegetation. Ecol. Appl. 2000, 10, 423-436. [CrossRef]

15. Scharlemann, J.; Hiederer, R.; Kapos, V. Global Map of Terrestrial Soil Organic Carbon Stocks; UNEP-WCMC\&EU-JRC: Cambridge, UK, 2009.

16. Hiederer, R. Distribution of Organic Carbon in Soil Profile Data. EUR 23980 EN; Office for Official Publications of the European Communities: Luxembourg, 2009; p. 126.

17. Batjes, N.H. Soil Property Values for Broad-Scale Modelling (WISE30sec) with Estimates of Global Soil Carbon Stocks. Geoderma 2016, 269, 61-68. [CrossRef] 
18. Scharlemann, J.P.W.; Tanner, E.V.J.; Hiederer, R.; Kapos, V. Global Soil Carbon: Understanding and Managing the Largest Terrestrial Carbon Pool. Carbon Manag. 2014, 5, 81-91. [CrossRef]

19. Lal, R. Food security impacts of the "4 per Thousand" initiative. Geoderma 2020, 374, 114427. [CrossRef]

20. Yigini, Y.; Panagos, P. Assessment of Soil Organic Carbon Stocks under Future Climate and Land Cover Changes in Europe. Sci. Total Environ. 2016, 557-558, 838-850. [CrossRef]

21. IPCC. Summary for policy makers. In Climate Change 2013: The Physical Science Basis, Contribution of Working Group I to the Fifth Assessment Report of the Intergovernmental Panel on Climate Change; Stocker, T., Qin, D., Plattner, G., Tignor, M., Allen, S., Boschung, J., Nauels, A., Xia, Y., Bex, V., Midgley, P., Eds.; Cambridge University Press: Cambridge, UK; New York, NY, USA, 2013; pp. 1-30.

22. Wiesmeier, M.; Barthold, F.; Spörlein, P.; Geuß, U.; Hangen, E.; Reischl, A.; Schilling, B.; Angst, G.; von Lützow, M.; Kögel-Knabner, I. Estimation of Total Organic Carbon Storage and Its Driving Factors in Soils of Bavaria (Southeast Germany). Geoderma 2014, 67-78. [CrossRef]

23. Hobley, E.U.; Baldock, J.; Wilson, B. Environmental and Human Influences on Organic Carbon Fractions down the Soil Profile. Agric. Ecosys. Environ. 2016, 223, 152-166. [CrossRef]

24. Hobley, E.; Wilson, B.; Wilkie, A.; Gray, J.; Koen, T. Drivers of Soil Organic Carbon Storage and Vertical Distribution in Eastern Australia. Plant Soil 2015, 390, 111-127. [CrossRef]

25. Novara, A.; Favara, V.; Novara, A.; Francesca, N.; Santangelo, T.; Columba, P.; Chironi, S.; Ingrassia, M.; Gristina, L. Soil Carbon Budget Account for the Sustainability Improvement of a Mediterranean Vineyard Area. Agronomy 2020, 10, 336. [CrossRef]

26. Napoli, M.; Dalla Marta, A.; Zanchi, C.A.; Orlandini, S. Assessment of Soil and Nutrient Losses by Runoff under Different Soil Management Practices in an Italian Hilly Vineyard. Soil Tillage Res. 2017, 168, 71-80. [CrossRef]

27. Rodrigo-Comino, J. Five Decades of Soil Erosion Research in 'Terroir'. The State-of-the-Art. Earth-Sci. Rev. 2018, 179, 436-447. [CrossRef]

28. Le Bissonnais, Y.; Blavet, D.; De Noni, G.; Laurent, J.-Y.; Asseline, J.; Chenu, C. Erodibility of Mediterranean Vineyard Soils: Relevant Aggregate Stability Methods and Significant Soil Variables. Eur. J. Soil Sci. 2007, 58, 188-195. [CrossRef]

29. Martínez-Casasnovas, J.A.; Concepción Ramos, M. Soil Alteration Due to Erosion, Ploughing and Levelling of Vineyards in North East Spain. Soil Use Manag. 2009, 25, 183-192. [CrossRef]

30. Belmonte, S.A.; Celi, L.; Stahel, R.J.; Bonifacio, E.; Novello, V.; Zanini, E.; Steenwerth, K.L. Effect of Long-Term Soil Management on the Mutual Interaction Among Soil Organic Matter, Microbial Activity and Aggregate Stability in a Vineyard. Pedosphere 2018, 28, 288-298. [CrossRef]

31. Chiti, T.; Gardin, L.; Perugini, L.; Quaratino, R.; Vaccari, P.; Franco, F.; Valentini, V. Soil organic carbon stock assessment for the different cropland land uses in Italy. Biol. Fertil. Soils 2012, 48, 9-17. [CrossRef]

32. Martin, M.P.; Wattenbach, M.; Smith, P.; Meersmans, J.; Jolivet, C.; Boulonne, L.; Arrouays, D. Spatial Distribution of Soil Organic Carbon Stocks in France. Biogeosciences 2011, 5, 1053-1065. [CrossRef]

33. Rodríguez-Murillo, J.C. Organic Carbon Content under Different Types of Land Use and Soil in Peninsular Spain. Biol. Fertil. Soils 2001, 33, 53-61. [CrossRef]

34. Liu, X.; Herbert, S.J.; Hashemi, A.M.; Zhang, X.; Ding, G. Effects of Agricultural Management on Soil Organic Matter and Carbon Transformation; a Review. Plant Soil Environ. 2011, 52, 531-543. [CrossRef]

35. Jakšić, S.; Milić, S.; Ninkov, J. Basic chemical properties of the soil. In Pedological and Agrochemical Properties of the Tri Morave Wine Region; Ninkov, J., Ed.; Institute of Field and Vegetable Crops: Novi Sad, Serbia, 2016.

36. Ivanišević, D.; Jakšić, D.; Korać, N. Vineyard Atlas; Republican Bureau of Statistics: Belgrade, Serbia, 2015.

37. Tomic, N.; Kokovic, J.; Jaksic, D.; Ninkov, J.; Vasin, J.; Malicanin, M.; Markovic, S. Terroir of the Tri Morave Wine Region (Serbia) as a Basis for Producing Wines with Geographical Indication. Geogr. Pannon. 2017, 21, 166-178. [CrossRef]

38. ISO/IEC 17025:2017. General Requirements for the Competence of Testing and Calibration Laboratories; Institute for Standardization of Serbia: Belgrade, Serbia, 2017.

39. ISO 11464:2006. Soil Quality—Pretreatment of Samples for Physico-Chemical Analysis; Institute for Standardization of Serbia: Belgrade, Serbia, 2006.

40. ISO 10390:2005. Soil Quality—Determination of $p H$; Institute for Standardization of Serbia: Belgrade, Serbia, 2005.

41. ISO 10693:1995. Soil Quality_Determination of Carbonate Content_Volumetric Method; Institute for Standardization of Serbia: Belgrade, Serbia, 1995.

42. ISO 106941995. Soil Quality—Determination of Organic and Total Carbon after Dry Combustion (Elementary Analysis); Institute for Standardization of Serbia: Belgrade, Serbia, 1995.

43. Van Reeuwijk, L.P. Procedures for Soil Analysis, 6th ed.; ISRIC FAO Technical Paper Vol. 9; International Soil Reference and Information Centre Wageningen: Wageningen, The Netherlands, 2002.

44. Ninkov, J. Karakterizacija Zemljišta Niškog Vinogradarskog Rejona; Institute of Field and Vegetable Crops: Novi Sad, Serbia, 2014.

45. Leake, S. Vineyard Soil Management; Sydney Environmental \& Soil Laboratory Pty Ltd.: Sydney, Australia, 1999.

46. White, R.E. Soils for Fine Wines; Oxford University Press: New York, NY, USA, 2003.

47. Gücüyen, A. Manisa ili ve Çevresinde Bă̆cılıkta Mekanizasyon Durumu, Sorunları ve iyi Tarım Uygulamalarına Yönelik Çözüm Önerileri; Ege Üniversitesi Fen Bilimleri Enstitüsü: İzmir, Turkey, 2007; p. 146s. (In Turkish)

48. Kaĉinskij, N.A. Mehaničeskij i Mikroagregatnij Sostav Počvi, Metodi Ego Izučenija; Izdateljstvo Akademi nauk SSSR: Moskva, Russia, 1958. 
49. Vučić, N. Water, Air and Soil Temperature Regime; Matica srpska Novi Sad, Faculty of Agriculture University of Novi Sad: Novi sad, Serbia, 1987.

50. Doğan, B.; Gülser, C. Assessment of Soil Quality for Vineyard Fields: A Case Study in Menderes District of Izmir, Turkey. Eurasian J. Soil Sci. 2019, 8, 176-183. [CrossRef]

51. Vidojević, D. Estimation of Soil Organic Matter in the Soils of Serbia; Faculty of Agriculture: Novi Sad, Serbia, 2015.

52. Smith, W.N.; Desjardins, R.L.; Pattey, E. The Net Flux of Carbon from Agricultural Soils in Canada 1970-2010. Glob. Chang. Biol. 2000, 6, 557-568. [CrossRef]

53. Arrouays, D.; Deslais, W.; Badeau, V. The carbon content of topsoil and its geographical distribution in France. Soil Use Manag. 2001, 17, 7-11. [CrossRef]

54. Gardi, C.; Sconosciuto, F. Evaluation of carbon stock variation in Northern Italian soils over the last 70 years. Sustain. Sci. 2007, 2, 237-243. [CrossRef]

55. Morari, F.; Lugato, E.; Berti, A.; Giardini, L. Long-Term Effects of Recommended Management Practices on Soil Carbon Changes and Sequestration in North-Eastern Italy. Soil Use Manag. 2006, 22, 71-81. [CrossRef]

56. Novara, A.; Minacapilli, M.; Santoro, A.; Rodrigo-Comino, J.; Carrubba, A.; Sarno, M.; Venezia, G.; Gristina, L. Real Cover Crops Contribution to Soil Organic Carbon Sequestration in Sloping Vineyard. Sci. Total Environ. 2019, 652, 300-306. [CrossRef]

57. Robinson, C.A.; Cruse, R.M.; Kohler, K.A. Soil management. In Sustainable Agricultural Systems; Hatfield, J.L., Karlen, D.L., Eds.; Lewis Publ.: Boca Raton, FL, USA, 1994; pp. 109-134.

58. Kladivko, E.J. Tillage Systems and Soil Ecology. Soil Tillage Res. 2011, 61, 61-76. [CrossRef]

59. Beare, M.H.; Hendrix, P.F.; Cabrera, M.L.; Coleman, D.C. Aggregate-Protected and Unprotected Organic Matter Pools in Conventional- and No-Tillage Soils. Soil Sci. Soc. Am. J. 1994, 58, 787-795. [CrossRef]

60. Buckman, H.O.; Brady, N.C. The Nature and Properties of Soil, 6th ed.; MacMillan: New York, NY, USA, 1960.

61. Belić, M.; Manojlović, M.; Nešić, L.J.; Ćirić, V.; Vasin, J.; Benka, P.; Šeremešić, S. Significance of Soil Organic Carbon Stock in Southe-Eastern Panonnian Basin. Carpathian J. Earth Environ. Sci. 2013, 1, 171-178.

62. Schöning, I.; Totsche, K.U.; Kögel-Knabner, I. Small Scale Spatial Variability of Organic Carbon Stocks in Litter and Solum of a Forested Luvisol. Geoderma 2006, 136, 631-642. [CrossRef]

63. Grüneberg, E.; Ziche, D.E.; Wellbrock, N. Organic carbon stocks and sequestration rates of forest soils in Germany. Glob. Chang. Biol. 2014, 20, 2644-2662. [CrossRef] [PubMed]

64. Ćirić, V. Kvalitativne i kvantitativne karakteristike organske materije različitih tipova zemljišta. In Doktorska Disertacija; Poljoprivredni Fakultet: Novi Sad, Serbia, 2013.

65. Vasques, G.M.; Grunwald, S.; Comerford, N.B.; Sickman, J.O. Regional Modelling of Soil Carbon at Multiple Depths within a Subtropical Watershed. Geoderma 2010, 156, 326-336. [CrossRef]

66. Wiesmeier, M.; Urbanski, L.; Hobley, E.; Lang, B.; von Lützow, M.; Marin-Spiotta, E.; van Wesemael, B. Soil Organic Carbon Storage as a Key Function of Soils-A Review of Drivers and Indicators at Various Scales. Geoderma 2019, 333, 149-162. [CrossRef]

67. Yu, H.Y.; Zha, T.; Zhang, X.; Ma, L. Vertical Distribution and Influencing Factors of Soil Organic Carbon in the Loess Plateau, China. Sci. Total Environ. 2019, 693, 133632. [CrossRef] [PubMed]

68. Meng, G.; Tong-Gang, Z.H.A.; Xiao-Xia, Z.; Zhi-Qiang, Z.; Yu-Shen, Z.H.U.; Ya, Z.; Yi-Han, L.I.U.; Zhu, L.I.N. Effects of Vegetation Type and Terrain on Vertical Distribution of Soil Organic Carbon on abandoned Farmlands in the Loess Plateau. Chin. J. Ecol. 2017, 36, 2447.

69. Van den Bygaart, A.J.; Gregorich, E.G.; Angers, D.A.; McConkey, B.G. Assessment of the Lateral and Vertical Variability of Soil Organic Carbon. Can. J. Soil Sci. 2007, 87, 433-444. [CrossRef]

70. Popović, T.; Mijović, S.; Pajović Šćepanović, R.; Raičević, D. Analysis of possibilities of reducing the quantity of mineral fertilizer application using different types of organic fertilizers in Cardinal grape variety. Agric. For. 2020, 66, 261-268. [CrossRef]

71. Ozdemir, G. Determination of the effect of some organic and organo-mineral fertilizers on total phenolic, flavonoid and anthocyanin content of Bogazkere (Vitis vinifera L.) grapes. Fresenius Environ. Bull. 2018, 27, 3199-3205.

72. Malusà, E.; Laurenti, E.; Ghibaudi, E.; Rolle, L. Influence of organic and conventional management on yield and composition of grape cv. "Grignolino". Acta Hortic. 2004, 640, 135-141. [CrossRef]

73. Blidariu, C.; Sala, F. Influence of organic and mineral fertilization on sugar content in Italian Riesling grape variety. J. Hortic. For. Biotechnol. 2012, 16, 251-254.

74. Yang, X.M.; Zhang, X.P.; Fang, H.J.; Zhu, P.; Ren, J.; Wang, L.C. Effects of fertilization under continuous on organic carbon in black soil: Simulation by RothC-26.3 model. Agric. Sci. China 2003, 36, 1318-1324.

75. Liu, X.; Liu, J.; Xing, B.; Herbert, S.J.; Meng, K.; Han, X.; Zhang, X. Effects of Long-Term Continuous Cropping, Tillage, and Fertilization on Soil Organic Carbon and Nitrogen of Black Soils in China. Commun. Soil Sci. Plant Anal. 2005, 36, 1229-1239. [CrossRef]

76. Hao, Y.; Lal, R.; Owens, L.B.; Izaurralde, R.C.; Post, W.M.; Hothem, D.L. Effect of Cropland Management and Slope Position on Soil Organic Carbon Pool at the North Appalachian Experimental Watersheds. Soil Tillage Res. 2002, 68, 133-142. [CrossRef]

77. Biddoccu, M.; Zecca, O.; Audisio, C.; Godone, F.; Barmaz, A.; Cavallo, E. Assessment of long-term soil erosion in a mountain vineyard, Aosta Valley (NW Italy). Land Degrad. Dev. 2018, 29, 617-629. [CrossRef]

78. Freibauer, A.; Rounsevell, M.D.A.; Smith, P.; Verhagen, J. Carbon Sequestration in the Agricultural Soils of Europe. Geoderma 2004, 122, 1-23. [CrossRef] 
79. Triberti, L.; Nastri, A.; Giordani, G.; Comellini, F.; Baldoni, G.; Toderi, G. Can Mineral and Organic Fertilization Help Sequestrate Carbon Dioxide in Cropland? Eur. J. Agron. 2008, 29, 13-20. [CrossRef]

80. Garcia Diaz, A.; Sastre, B.; Aton, O. The influence of the soil management strategy on the soil organic carbon concentration in meditarrean vineyards. In Proceedings of the 1st World Conference on Soil and Water Conservation under Global ChangeCONSOWA, Lleida, Spain, 12-16 June 2017.

81. Cervantes, V.A.; Don, A.; Well, R.; Schneider, F.; Nieder, R. Deep ploughing mineral soils for SOC sequestration. In Global Symposium on Soil Organic Carbon; FAO: Rome, Italy, 2017.

82. Arshad, M.A.; Schnitzer, M.; Angers, D.A.; Ripmeester, J.A. Effects of till vs. no-till on the quality of soil organic matter. Soil Biol. Biochem. 1990, 22, 595-599. [CrossRef]

83. Dalal, R.C.; Henderson, P.A.; Glasby, J.M. Organic matter and microbial biomass in a Vertisol after 20 yr. of zero-tillage. Soil Biol. Biochem. 1991, 23, 435-441. [CrossRef]

84. Ding, G.; Novak, J.M.; Amarasiriwardena, D.; Hunt, P.G.; Xing, B. Soil organic matter characteristics as affected by tillage management. Soil Sci. Soc. Am. J. 2002, 66, 421-429. [CrossRef]

85. Campbell, C.A.; Selles, F.; Lafond, G.P.; Biederbeck, V.O.; Zentner, R.P. Tillage-fertilizer changes: Effect on some soil quality attributes under long-term crop rotation in a thin Black Chernozem. Can. J. Soil Sci. 2001, 81, 157-165. [CrossRef]

86. Liebig, M.A.; Tanaka, D.L.; Wienhold, B.J. Tillage and cropping effects on soil quality indicators in the northern Great Plains. Soil Tillage Res. 2004, 78, 131-141. [CrossRef]

87. Vos, C.; Don, A.; Hobley, E.U.; Prietz, R.; Heidkamp, A.; Freibauer, A. Factors Controlling the Variation in Organic Carbon Stocks in Agricultural Soils of Germany. Eur. J. Soil Sci. 2019, 70, 550-564. [CrossRef]

88. Meersmans, J.; De Ridder, F.; Canters, F.; De Baets, S.; Van Molle, M. A Multiple Regression Approach to Assess the Spatial Distribution of Soil Organic Carbon (SOC) at the Regional Scale (Flanders, Belgium). Geoderma 2008, 143, 1-13. [CrossRef]

89. Meersmans, J.; Martin, M.P.; Lacarce, E.; De Baets, S.; Jolivet, C.; Boulonne, L.; Lehmann, S.; Philippe, N.; Saby, A.; Bispo, A.; et al. A High Resolution Map of French Soil Organic Carbon. Agron. Sustain. Dev. 2012, 32, 841-851. [CrossRef]

90. Travnikova, L.S.; Titova, N.A.; Kogut, B.M.; Schulz, E.; Körschens, M. Evaluation of the Different Soil Organic Matter (SOM) Pools Stability in Long-Term Field Experiments of Germany by Physical Fractionation. Arch. Agron. Soil Sci. 2002, 48, 565-576. [CrossRef]

91. Rice, C.W. Organic matter and nutrient dynamics. In Encyclopedia of Soil Science; Marcel Dekker Inc.: New York, NY, USA, 2002; pp. 925-928.

92. Prasad, R.; Power, J.F. Soil Fertility Management for Sustainable Agriculture; Lewis Publishers in an Imprint of CRC Press: Boca Raton, FL, USA, 1997; p. 243.

93. Li, Y.; Wang, X.; Niu, Y.; Lian, J.; Luo, Y.; Chen, Y.; Gong, X.; Yang, H.; Yu, P. Spatial Distribution of Soil Organic Carbon in the Ecologically Fragile Horqin Grassland of Northeastern China. Geoderma 2018, 325, 102-109. [CrossRef]

94. Islam, K.K.; Anusontpornperm, S.; Kheoruenromne, I.; Thanachit, S. Relationship between Carbon Sequestration and PhysicoChemical Properties of Soils in Salt-Affected Areas, Northeast Thailand. Kasetsart J. Nat. Sci. 2014, 48, 560-576.

95. Ayaz, M.; Akhtar, M.; Rukh, S.; Imran, M.; Hassan, A.; Abbasi, K.; Qayyum, A. Soil Organic Carbon Stock Variation with Climate and Land Use in Shale Derived Soils. J. Serbian Chem. Soc. 2018, 83, 785-793. 